\title{
THE LATIN OF THE INSCRIPTIONS IN NARBONENSIS: SOME PHONETIC CHARACTERISTICS*
}

\begin{abstract}
Summary: The present paper aims at examining the phonetic characteristics of the Latin in Narbonensis as reflected by the local inscriptions. Data will be presented from a limited corpus: from Fréjus (Forum Iulii), Antibes (Antipolis), Riez (Reii Apollinares), Digne (Dinia), Aix-en-Provence (Aquae Sextiae), Apt (Apta Iulia), Vienne (Vienna) and their territories. The inscriptions from these areas have been republished recently with the addition of some newly discovered inscriptions. Thus, this epigraphic material needs reconsideration in order to see whether the data collected from the new annotated edition corroborate or refute the existing findings of Vulgar Latin research.
\end{abstract}

Key words: Narbonensis, Vulgar Latin, Romanization, epigraphic activity, inscriptions, vocalism, consonantism, József Herman

In the twentieth century, a new approach started to dominate the research of Vulgar Latin: the microphilological method, which implies the meticulous collection and classification of the corpus under examination and its evaluation on quantitative grounds. This method aims at discovering the micro-structure of the linguistic phenomena under examination. ${ }^{1}$ Basically, this is the approach which underlies Herman's preliminary guidelines for Late Latin data collection, ${ }^{2}$ which were finally real-

\footnotetext{
${ }^{*}$ The present paper has been prepared within the project OTKA (Hungarian Scientific Research Fund) No. K 62032 entitled "Computerized Historical Linguistic Data Base of Latin Inscriptions of the Imperial Age".

${ }^{1}$ Cf. Herman, J.: Differenze territoriali nel latino parlato dell'Italia tardo-imperiale: un contributo preliminare. In HERMAN, J. - MARINETTI, A. (edd.): La preistoria dell'italiano. Atti della Tavola Rotonda di Linguistica Storica. Università Ca' Foscari di Venezia 11-13 giugno 1998. Tübingen 2000, 123-135; esp. 124-127. $1990 / 1991$

${ }^{2}$ See Herman, J.: Late Latin Data Base: Guidelines for Data Collection. Manuscript. Budapest
} 
ized in the Computerized Historical Linguistic Data Base of Latin Inscriptions of the Imperial Age $(L L D B)^{3}$

Following Herman's microphilological approach, in the present paper I intend to deal with the phonetic characteristics of the Latin in Narbonensis as reflected by the inscriptions I have processed so far. This means that data will be presented from a limited corpus, not from the whole of the province Narbonensis. Thus, one should first consider the limitations of this corpus and explain why it is relevant in drawing valid conclusions from the Vulgar Latin data offered by it.

Within the framework of the project aiming at establishing a computerized database of Late Latin inscriptions, I started to study the inscriptions of Narbonensis two years ago. Since then, inscriptions from the following areas of Narbonensis have been processed: Fréjus (Forum Iulii) and its territory, Antibes (Antipolis) and its territory, Riez (Reii Apollinares) and its territory, Digne (Dinia) and its territory, Aixen-Provence (Aquae Sextiae) and its territory, Apt (Apta Iulia) and its territory, and Vienne (Vienna) and its territory. This roughly totals up to a third of the whole area of Narbonensis. Thus the question arises what the relevance of these data is. The last extensive monography on the language of the inscriptions in Gaul written by Jules Pirson was published in $1901{ }^{4}$ that is, more than a hundred years ago. For Narbonensis, Pirson could only process the inscriptions published in CIL $12 .{ }^{5}$ Since then, new inscriptions have been found, which were partly published in the L'Année Épigraphi$q u e$, and partly in new collections, for instance in Espérandieu's $I L G N{ }^{6}$ Between 1985 and 2005, the inscriptions of the afore-mentioned areas of Narbonensis were published in the series Inscriptions latines de Narbonnaise (ILN) in seven volumes under the direction of B. Rémy. ${ }^{7}$ Apart from the inscriptions already published in $C I L$ 12, the new annotated edition contains inscriptions that have appeared in the $A E$ or in other collections so far and numerous inedited inscriptions as well. Thus, the data collected from the new annotated edition can definitely complement our knowledge about the Latin language either by corroborating or by refuting the existing findings.

After introducing the corpus under examination, the epigraphic activity in Narbonensis is to be outlined briefly. The number of inscriptions in Narbonensis is relatively small, in a $1000 \mathrm{~km}^{2}$ unit of area 6.1 inscriptions can be found in average. ${ }^{8}$

\footnotetext{
${ }^{3}$ See http://lldb.elte.hu/.

${ }_{5}^{4}$ PIRSON, J.: La langue des inscriptions latines de la Gaule. Bruxelles 1901.

${ }^{5}$ CIL $12=$ HIRSCHFELD, O.: Inscriptiones Galliae Narbonensis Latinae. Berlin 1888.

${ }^{6}$ ILGN = ESPÉRANDIEU, É.: Inscriptions Latines de Gaule (Narbonnaise). Paris 1929.

${ }^{7}$ The seven volumes are the following: ILN 1 = GASCOU, J. - JANON, M.: Inscriptions latines de Narbonnaise -Fréjus, $44^{\mathrm{e}}$ suppl. à Gallia. Paris 1985; ILN 2 = CHASTAGNOL, A.: Inscriptions latines de Narbonnaise II - Antibes, Riez, Digne, 44 ${ }^{\mathrm{e}}$ suppl. à Gallia. Paris 1992; ILN 3 = GASCOU, J.: Inscriptions latines de Narbonnaise - III. Aix-en-Provence, 44 suppl. à Gallia. Paris 1995; ILN 4 = GASCOU, J. - LEVEAU, PH. - Rimbert, J.: Inscriptions latines de Narbonnaise - IV. Apt, 44 ${ }^{\mathrm{e}}$ suppl. à Gallia. Paris 1997; ILN 5.1 = BERTRANDY, F. - KAYSER, F. - PELlETIER, A. - RÉMY, B. - WiBle, F.: Inscriptions latines de Narbonnaise - V. 1. Vienne, $44^{\mathrm{e}}$ suppl. à Gallia. Paris 2004; ILN 5.2 = KAYSER, F. - Pelletier, A. RÉMY, B. - WiBlE, F.: Inscriptions latines de Narbonnaise - V. 2. Vienne, $44^{\mathrm{e}}$ suppl. à Gallia. Paris 2004; ILN 5.3 = KAYSER, F. - Pelletier, A. - RÉMY, B. - WiBle, F.: Inscriptions latines de Narbonnaise - V. 3. Vienne, $44^{\mathrm{e}}$ suppl. à Gallia. Paris 2005.

${ }^{8}$ Woolf, G.: Becoming Roman: The Origins of Provincial Civilization in Gaul. Cambridge 1998, 83.
} 
In comparison to this, in some parts of Italy more than 200 inscriptions occur in an area of the same size. ${ }^{9}$ The earliest Latin inscriptions in Narbonensis can be dated to the middle of the fist century BC or even earlier.

The distribution of the inscriptions is uneven in Narbonensis. Its epigraphic picture reflects the colonial system and its rearrangement in the ages of Caesar and Augustus. Major clusters of inscriptions can be found in its capital, Narbo Martius (Narbonne), in the veterans' colonies of Arelate (Arles), Baeterrae (Béziers), Arausio (Orange), Forum Iulii (Fréjus), and in major native centres established before the Romans' arrival, in Nemausus (Nîmes), Vasio (Vaison), and Die. ${ }^{10}$ The great number of the colonies - compared to the area of Narbonensis - and the stable and continuous linguistic communities in these colonies contributed to the relatively fast extension of the Latin language to the whole population of the province. ${ }^{11}$

The inscribing classes in Narbonensis can be well illustrated through the inscriptions of Narbo Martius, which is the oldest colony in Gaul. From this colony, more than a thousand inscriptions have been preserved, which suggests an "intense epigraphic activity compared to most Gallic cities." ${ }^{.2}$ On these inscriptions, approximately 1800 persons are named, but out of them the status of only a 1000 persons can be identified. A third is made up of freeborn citizens of the colony: merchants, soldiers and veterans. The remaining two thirds are liberti from various levels of society: officials, artisans, shopkeepers. However, some social groups are underrepresented: only 15 slaves appear on these inscriptions and there is no information about liberti of lower social status.

After the brief overview of the epigraphic activity in Narbonensis, the phonetic characteristics of its Latin language are to be presented as reflected by the data processed and analysed. First the characteristics of the vowel system will be described, which will be followed by the discussion of the consonantism.

\section{VOCALISM}

From the corpus examined, 333 data have been collected that characterize the vowel system of the Latin in Narbonensis.

1. Monophthongization of ae to open $e$. In the corpus, the monophthongization of $a e$ to short open $e$ is indicated in writing in approximately 60 cases. In more than fifty cases, monophthongization is marked in an unstressed syllable. The vowels affected by monophthongization are generally the feminine case-ending -ae in the first

${ }^{9} \mathrm{Cf}$. the map showing the epigraphic density in the Western provinces in WoOLF (n. 8) 82.

${ }^{10}$ WoOlf (n. 8) 90 .

${ }^{11}$ Compared to the situation in Narbonensis, in the Tres Galliae the Latin language could spread more slowly and gradually in the areas located far from the urban centres, as only three colonies (Lyon, Nyon and Augst) could promote the process of Latinization. See HERMAN, J.: La situation linguistique dans la Gallia Narbonensis et les origines de la séparation du domaine français et du domaine provençal. In Atti del XXI. Congresso Internazionale di Linguistica e Filologia Romanza: Università di Palermo 18-24 settembre 1995. Ed. G. RUFFINO. Tübingen 1998, 456-457.

${ }_{12}^{12}$ WoOLF (n. 8) 98. 
declension; there are only four exceptions: \{ET\}ETERNALEM (aeternalem, ILN 2, R 25, 4-5), ETERNAE (aeternae, ILN 5.1, 163, 2 and 243, 3) and PRES[ENTE] (Praesente, ILN 5.3, 626, 3). The oldest examples for monophthongization in an unstressed syllable (ILN 3, 142, 2 and ILN 2, A 86, 1) date from the age of the JulioClaudian dynasty. However, the first example for monophthongization indicated in a stressed syllable appears only slightly later, at the end of the first century AD. In the corpus, some hypercorrect forms (6 items) also attest the change, where the number of data with $A E$ for short $\breve{e}$ is equal to the number of forms with $A E$ for long $\bar{e} .^{13}$

2. $a e>A I{ }^{14}$ In the corpus, there are four instances where $A I$ can be found for the digraph $A E$. All instances are proper names in the dative. ${ }^{15}$ The phenomenon is usually classified as an archaism, but alternative interpretations also exist. In his article analysing the epigraphic material of Aquae Sextiae, J. Gascou identifies this phenomenon as hyperurbanism: in the urban speech, the diphthong ae might have been overarticulated in an affected manner, which seems to be reflected by the digraph $A I$ in writing. ${ }^{16}$ However, three of these instances ${ }^{17}$ might as well reflect Emperor Claudius' (41-54) reform, according to which the first declension dative case ending was to be written with the digraph $A I$, so that the dative could easily be distinguished from the genitive ending written with $A E$.

3. $E \sim I .{ }^{18} 21$ data show the influence of the Vulgar Latin phonetic development whereby long $\bar{e}$ and short $\breve{l}$ merged into an identical phoneme, into closed $e$ in most areas of the Roman Empire. Hypercorrect forms also betray this general process, e.g. MILIX (miles, ILN 4, 26, 4; dat. 101-160). However, there is no firm evidence for $E$ written for long $\bar{l}$ in the corpus. Roughly in two thirds of the data the merging affects an unstressed syllable.

4. $O \sim V$. Later, the same phonetic development took place among the velar vowels as well: long $\bar{o}$ and short $\breve{u}$ merged into closed $o$. However, in the corpus, strictly speaking, only one - fairly late (third-century) - example illustrates this phenomenon: the form GVTICO (Gothico, ILN 5.3, 913, 8), where $V$ is written for $O$ in a stressed syllable. The other examples, however, can be interpreted in some other way as well. For instance, the form MENSVR $[(I L N 4,90,1)$ can be the abbreviation

\footnotetext{
${ }^{13}$ In such hypercorrect forms, the replacement of an original short $\check{e}$ with $A E$ is more general than that of an original long $\bar{e}$, which might suggest that the pronunciation of the diphthong ae was similar to that of the short ĕ. Cf. SCHUCHARDT, H.: Der Vokalismus des Vulgärlateins. Vol. 1. Leipzig 1866, 460-461.

${ }^{14}$ Here, the symbol $>$ means "represented in the text as," for instance $\breve{a}>E$ would mean "a sound which should be a short unaccented $a$ following usual norm is represented in the text by a letter $E$ '. See HERMAN: Late Latin Data Base (n. 2) 10.

${ }^{15}$ This phenomenon is characteristic of proper names in the genitive or dative; Pirson can only cite two common nouns displaying $A I$ instead of $A E$ (piai, CIL 12, 789 and ancil(l)a(i), CIL 12, 1412). See PIRSON (n. 4) 18.

${ }^{16}$ GASCOU, J.: Quelques particularités de la langue des inscriptions latines d'Aquae Sextiae. In $\mathrm{La}$ langue des inscriptions latines de la Gaule. Actes de la Table-ronde tenue au C.E.R.G.R. les 6 et 7 octobre 1988. Ed. J. GASCOU. Lyon 1989, 14.

${ }^{17}$ The form VAEERIAI (Valeriae, ILN 4, 46, 1) is dated earlier than the reign of Claudius. $E$ for $L$ is possibly a scribal error.

${ }^{18}$ The symbol $\sim$ means 'alternates with', see HERMAN: Late Latin Data Base (n. 2) 10.
} 
of either mensores or mensuratores. ${ }^{19}$ In numerous cases, the sequence -VOS can be found for -VVS in word-final position, e.g. in VIVOS. However, this variation is usually not the result of the above mentioned merging of velar vowels, instead, it is the archaic way of writing the vowel $u$ after the bilabial $v$. Thus, it is only a question of orthography, it does not correspond to any phonetic fact.

5. $\bar{l}>E I$. In three cases, the digraph $E I$ is written for an original long $\bar{l}$. According to Pirson, the phenomenon can be classified as archaism appearing in writing. ${ }^{20}$ However, we can count with a Graecism at least in the case of the name I $\triangle$ APEI ( $\mathrm{Hi}$ lari, ILN 5.1, 160, 2, dat. 151-200) written in Greek characters, since the Latin long $\bar{l}$ was usually transcribed as $\varepsilon 1$ in Greek and vice versa.

6. Unstressed, prevocalic $i$ and $e$. Unstressed, prevocalic $i$ and $e$ in hiatus lost their syllabic value and turned into the semivowel $j$ and could also be eliminated. ${ }^{21}$ In the corpus, the number of examples showing the confusion between $i$ and $e$ in this phonetic position approximately equals the amount of data where unstressed prevocalic $i$ or $e$ became eliminated. The corresponding change of $o$ and $u$ in hiatus to the semivowel $w$ is not recorded in this epigraphic material.

7. Syncope. There is a limited number of examples for syncope in the corpus. The elimination of the vowel $u$ between $c$ and $l$ is the most widespread form of syncope; ${ }^{22}$ the majority of the examples from Narbonensis illustrate this phenomenon. In one case, the stressed vowel was eliminated: SENCIO (Senecio or Senicio, ILN 3, 226, 4; dat. 101-300).

8. $i>V$. Numerous examples illustrate the confusion between the vowels $i$ and $u$. Since Caesar's age, forms containing the vowel $i$ had been accepted as normative, ${ }^{23}$ this usage became established as the norm from the first century on. However, in some cases, forms with the vowel $u$ were retained as archaisms, especially when the phoneme $u$ is preceded by a syllable containing a velar vowel. In four instances out of the twenty examples, the use of $u$ instead of $i$ is not motivated phonetically, since the preceding syllable contains a palatal vowel, e.g. POTISSVMA (Potissima, ILN 3, 240, 2; dat. $27 \mathrm{BC}-37 \mathrm{AD}$ ). However, in the form MONIMENTV[M] (ILN $1,121,1)$ the phonetic environment should have led to the use of $-V$-; the application of $-I$ - might be interpreted as the hypercorrect restoration of the normative vowel.

9. Greek $Y$. The normative transcription of the Greek $Y$ was $Y$ in Latin, yet $V$ or $I$ are also used as alternatives. In the corpus under examination, transcription with $I$ occurs more often than with $V$, which is the more archaic solution. ${ }^{24}$ We can even find hypercorrect forms where $Y$ is written for the original $i$, e.g. GHOTYCVS (Gothicus, ILN 5.3, 914, 6; dat. 276). On a dedication to the Nymphs, it cannot be

\footnotetext{
${ }^{19}$ In the commentary written to the inscription, the interpretation mensur(atores) is given, cf. GASCOU-LEVEAU-RIMBERT (n. 7) 133.

${ }^{20}$ PIRSON (n. 4) 21.

${ }^{21}$ Herman, J.: Vulgar Latin. University Park, Pa. 2000, 35.

${ }^{22}$ Herman: Vulgar Latin (n. 21) 34-35.

${ }^{23}$ Cf. Quint. Inst. orat. 1. 7. 21: Iam optimus maximus ut mediam i litteram, quae veteribus u fuerat, acciperent primum Caesaris inscriptione traditur factum.

${ }^{24}$ PIRSON (n. 4) 39.
} 
decided whether NENPIS or NVNPIS is written on the stone $(\operatorname{ILN} 3,213,1)$, since the two vertical lines can either be interpreted as a cursive $E$ or as a carelessly cut $V^{25}$ 10. Finally, there are some isolated Vulgar Latin phenomena in the corpus:

- Prosthetic $i$ appears only once, in the form ISMARAGDVS (Smaragdus, ILN 5.1, 161, 5; dat. 176-225).

- An interesting form NYMPYIS $(I L N 4,105,1)$ appears in Apta Iulia. The commentator of the inscription in ILN 4 explains the strange ending with the lapicide's error, who possibly wrote $Y$ instead of the $H$ used for indicating aspiration. ${ }^{26}$ Pirson, however, discusses so-called parasite vowels ("voyelles parasites"), which were inserted next to the usual vowel indicating that the scribe hesitated whether he should follow the normative orthography or try to reflect the phonetic reality in writing. Pirson cites the form CHRYISIS (Brambach, Corpus Inscriptionum Rhenanarum, I 979) as an example. Here, the lapicide might have inserted the vowel $I$ to indicate that the grapheme $Y$, the sound value of which was dubious, was to be pronounced $i{ }^{27}$ The $Y$ in the ending of the form NYMPYIS might also be classified as a parasite vowel. In this case, however, hypercorrection is to be assumed, since the dative ending in the plural is -is. The inverse orthography might also have been induced by the normative $Y$ in the first syllable.

- The form COYLIA (ILN 1, 166, 3) in Forum Iulii is significant from the viewpoint of orthography. In the same name, the diphthong appears also as $O E$ (Coelius, ILN 1, 118, 6) and OI (Coilius, CIL 12, 5686) in Narbonensis. The digraph $O Y$ seems to be a later orthographic variant of the digraphs $O E$ and $O I{ }^{28}$

- In intervocalic position, the semivowel $j$ was always geminated, as it is proven by metrics: the first syllable of maior, peior etc. was regarded as long (cf. Verg. Aen. 7. 386: Maius adorta nefas, maioremque orsa furorem). ${ }^{29}$ This peculiarity of articulation appears once in writing in the corpus, in the form EIIVS (eius, ILN 5.1, 300, 11; dat. 151-225).

- Posttonic $-u$ - tends to be eliminated if preceded by $-u$ - or $-o$-. This development was also criticized by grammarians, for instance Charisius (4th c.) notes that "carduus trium syllabarum est" (Gramm. Lat. 1, 74, 34) because it was pronounced cardus in his time. ${ }^{30}$ In the corpus, one can find the form LACVVS twice (ILN 5.3, 843, 6 and 844, 5; dat. 41-75), which could be interpreted as a hypercorrect reaction to this tendency.

\footnotetext{
${ }^{25}$ The editor of the $I L N 3$ only gives the form NENPIS without offering the alternative NVNPIS, cf. GASCOU (n. 7) 277-278.

${ }^{26}$ The cursive forms of $H$ and $Y$ are not similar, which renders this hypothesis less probable. See the cursive letter forms on Plate 1 in CIL 4 = ZANGEMEISTER, C.: Inscriptiones Parietariae Pompeianae Herculanenses Stabianae. Berlin 1871.

${ }^{27}$ PIRSON (n. 4) 109-110.

${ }^{28}$ GASCOU-JANON (n. 7) 178.

${ }^{29}$ VÄÄNÄNEN, V.: Introduzione al latino volgare. Trad. A. Grandesso Silvestri. Bologna 1982, 111.

${ }^{30}$ VÄÄNÄNEN (n. 29) 103.
} 


\section{CONSONANTISM}

From the linguistic corpus under examination, 209 data have been collected that show Vulgar Latin processes in the consonant system.

1. Elimination of the word-initial laryngeal spirant. Since the tendency of eliminating the word-initial laryngeal spirant started well in the Republican age, ${ }^{31}$ in our corpus, its retention or elimination is a mere orthographic matter. We only have three firm examples for the omission of word-initial $h$ - in writing, in two further cases the interpretation is problematic. ${ }^{32}$ In two instances, the laryngeal spirant $h$-is inserted inversely.

2. Voicing of $-p-,-t-,-k-$. For the voicing of intervocalic voiceless stops, there is no firm evidence in this epigraphic material. In four instances from the third century, the form atque appears as adque, that is, with a voiced dental (ILN 3, 116, 2; ILN 5.2, 365, 8 and 366/1, 2 and 366/2, 2). However, this form might also be explained as analogical with the confusion between the preposition $a d$ and the conjunction at attested by Quintilian. ${ }^{33}$ The form SCRIBSIMVS for scripsimus (ILN 5.1, 190, 2; dat. 401-500) illustrates re-formation, an artificial restoration of the stem.

3. Devoicing of $-b-,-d-,-g-$. For devoicing of an intervocalic voiced stop, we have only one example in the corpus: TAVROPO[L]I for taurobolii (ILN 2, R 5, 6; dat. 160-200). ${ }^{34}$ The voiced dental $b$ is replaced for voiceless $p$ in OPST[ETRICI] (obstetrici, ILN 1, 30, 3) and OPTVLI[T] (obtulit, ILN 5.1, 303, 8; dat. 138-161) due to partial assimilation to the adjacent voiceless consonant. A mere instance illustrates devoicing in word-final position: QVIT for quid (ILN 3, 41/1, 11; dat. 151-200). Finally, there are several forms in which the graph $C$ can be found for $G$. However, this is only a question of orthography: in the archaic period, the graph $C$ could represent both the voiced and voicless velar stop. This tradition seems to linger on in the epigraphic material.

4. Intervocalic $-v-$. In Vulgar Latin, intervocalic $-v$ - was regularly lost, probably from late Republican times on. Pirson notes that bilabial $-v$ - is usually elided before the back vowels $o$ and $u$ and sometimes even before $e$ in Gaul. ${ }^{35}$ In this corpus, the overwhelming majority of the examples illustrate the loss of intervocalic $-v$ - before the back vowel $u$. However, in this epigraphic material intervocalic $-v$ - proves to be somewhat unstable in another position as well: it is elided before $-i$ - in two instances: IOI (Iovi, ILN 1, 148, 3; dat. 154-233) and POSIIT (posivit, ILN 5.1, 116, 5; dat.

${ }^{31}$ HERMAN: Vulgar Latin (n. 21) 38.

${ }^{32}$ ILN 1, 41, 3 (containing ERES) has been lost. Three transcriptions have been preserved, two of which offer the form ERES, while the remaining one has the abbreviation HER. See GASCOU-JANON (n. 7) 75-76. ILN 5.2, 574, 6 contains the form OMINES, which can either be interpreted as homines lacking the word-initial $h$ - or as omnes with an anaptyctic vowel.

${ }^{33}$ Quint. Inst. orat. 1. 7. 5: Illa quoque servata est a multis differentia, ut ad, cum esset praepositio, d litteram, cum autem coniunctio, $t$ acciperet. Cf. PIRSON (n. 15) 65. He also cites examples for the confusion at $\sim a d$ from Narbonensis: AD (=at) CIL 12, 1981 and 5691.

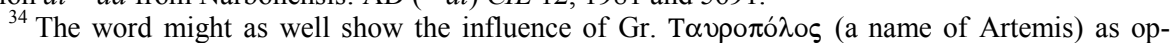
posed to $\tau \alpha v \rho \circ \beta$ ó $\lambda$ iov ('slaughter of a bull').

${ }^{35}$ PIRSON (n. 4) 62-63. 
1-100). ${ }^{36}$ Furthermore, we have two examples for the loss of $-v$ - between a liquid and a vowel: SERVM (servum, ILN 5.3, 739, 5) and SALVS (salvus, ILN 2, A 87, 3; 2nd c.). Finally, in one peculiar case, bilabial $-v$ - was intercalated in a hiatus to provide transition between the two vowels in pronunciation: EVVARISTVS (Euaristus, ILN 2, A 131, 3; dat. 1-200). ${ }^{37}$

5. Palatalization. There are only two sporadic examples for palatalization in the corpus. The form DIVICIVS for Divitius (ILN 5.1, 220, 4, dat. 151-200) shows the palatalization of dental $t$ before $i$. The hypercorrect form PORTIA for Porcia (ILN 5.1, 102, 6; dat. 151-200) also betrays the process of palatalization.

6. Geminated consonants. In the epigraphic material, geminated consonants tend to be simplified very frequently. However, in most cases, it cannot be decided whether this tendency reflects real phonetic processes or merely the archaic orthography. The reduction of the geminated consonants to single ones became more and more frequent near the end of the Empire, ${ }^{38}$ thus one can assume that the orthography shows a real phonetic development. In the corpus under examination, the geminated liquid $l$ in proper names and the spirant $s$ usually in superlatives tend to be reduced in most cases. In two instances, geminated $n$ is reduced. However, the reduction of $n$ in the form ANOS for annos $(I L N 4,47,5)$ is to be regarded as a mere orthographic phenomenon, since all of its Romance reflexes go back to the form annum, for instance It. anno, Fr. année. Two instances illustrate the reduction of geminated stops: ABVCIA for Abuccia (ILN 4, 126, 2; dat. 27 BC - 68 AD) and VRITEAE for Vrittiae (ILN 5.2, 422, 2; dat. 101-125). ${ }^{39}$ There is a further peculiar case: the simplification of the geminated liquid $r$ in the form TAERE for terrae (ILN 1, 201, 8-9). Pirson does not record any examples for this phenomenon, ${ }^{40}$ which must be a relatively late development; the form TAERE is also dated to the 4 th century. ${ }^{41}$

Corresponding to the reduction of geminated consonants, simple consonants sometimes appear as geminated inversely. However, fewer examples illustrate this phenomenon in the corpus. In most cases, simple $l$ and simple $s$ tend to be geminated, although the gemination of two stops also occurs in isolation in the forms DIVCCIVS for Diucius (ILN 4, 107, 3-4) ${ }^{42}$ and SVPPREMA for suprema (ILN 5.1, 256, 2; dat. 151-200).

${ }^{36}$ Cf. App. Probi 73. fauilla non failla; PISANI, V.: Testi latini arcaici e volgari con commento glottologico. Torino 1950, 172.

${ }^{3}$ VÄÄNÄNEN (n. 29) 100-101.

${ }^{38}$ HERMAN: Vulgar Latin (n. 21) 47-48.

${ }^{39}$ The reduction of geminated stops is a relatively infrequent phenomenon in the whole of Gaul, cf. PIRSON (n. 4) 89

${ }^{40}$ The inscription containing the form TAERE was published in the twelfth volume of the CIL, but there it appears as TAERRE (CIL 12, 5457, 8-9). Thus, Pirson could not cite this example in his monography. However, the reading published in the $C I L$ has been revised by the editors of the first volume of the ILN, cf. GASCOU-JANON (n. 7) 208.

${ }^{41}$ In the Appendix Probi, one can also find an example for this process: 182. garrulus non garulus; cf. PISANI (n. 36) 177.

${ }^{42}$ Although the nomen gentile of Celtic origin is a hapax legomenon in this form, its variant Diucius, $-a$ is well attested, see GASCOU-LEVEAU-RIMBERT (n. 7) 150. For the change $c>C C$ PIRSON (n. 4) 
7. Simplification of consonant groups. As for the simplification of consonant groups, the most frequent phenomenon is - as expected - the elimination of $-n$ - from the sequence $-n s-.{ }^{43}$ Apart from this, only one further firm example for simplification can be recorded: the group -nct- is simplified to -nt- in DEFVNTO (ILN 5.2, 335, 4-5; dat. 101-200). ${ }^{44}$

8. Assimilation and dissimilation. Consonant groups in the corpus tend to be resistant not only to simplification but to assimiliation as well; one can find only sporadic instances of assimilation. The sequence -ct- is assimilated in the form INVITO (ILN 5.3, 912, 7; dat. 274-275), while in SECVNELIAE (ILN 5.1, 184, 5) the sequence $-n d$ - underwent assimilation. ${ }^{45}$ Although the assimilation of the groups -rsand $-l s$ - is a comparatively infrequent phenomenon, both are attested in this epigraphic material: SVPESTES for Superstes (ILN 3, 157, 3-4; dat. 101-200) ${ }^{46}$ and DEPVSSORI for Depulsori (ILN 1, 148, 3-4; dat. 154-233). ${ }^{47}$ In one case, the assimilation of a word-final $n$ and a word-initial $m$ is indicated in writing: NOM MERENS (non merens, ILN 5.1, 282, 7; dat. 151-225). There is one more peculiarity that deserves mentioning, the form VOLVMTATE for voluntate (ILN 5.2, 369, 6; dat. 126-175). The word voluntas occurs in the following forms in inscriptions or in manuscripts: volumptas, volunptas, voluctas, voluptas. In Leumann's opinion, this diversity is caused by the contamination of the nouns voluntas and voluptas. The consonant clusters -ct-, -pt- and -nt- underwent assimilation to -tt-, which can induce hypercorrection in writing. ${ }^{48}$

Dissimilation is also sporadically attested in the corpus; it tends to be induced by re-formation, as in the cases CONLIG[IVM] for collegium (ILN 1, 50, 2; dat. 27 BC-14 AD) and CONLIBERTO for colliberto (ILN 5.2, 318, 6-7; dat. 151-200). In some instances, the original sequence - $m p$ - is dissimilated to $-n p$ - possibly following the analogy of the hypercorrect re-formation of comparavit to conparavit.

89 records several further examples (e.g. Deccius CIL 12, 3550; Deccia CIL 12, 1010; Maccarius CIL 12, 5686), the analogy of which might have contributed to the change in a nomen gentile of Celtic origin.

${ }^{43}$ HeRMAN: Vulgar Latin (n. 21) 47. This development is well attested already from the early period of the Republican times, cf. the abbreviation cos. for consul.

${ }^{44}$ In two instances, one can find the form CONIVX (ILN 5.1, 135, 4-5 and 5.2, 318, 4-5) with the elimination of $-n$ - before $x$. However, the form can be interpreted as a scribal error neglecting the $V N$ ligature.

${ }^{45}$ In $I L N$ 5.3, one can also find the form SCVLTVRA showing the assimilation -pt- > T / TT. However, according to L. Revon, SEPVLTVRA is to be read. Since the inscription is lost, no decision can be made between the two alternatives. Cf. RÉMY (n. 7) 152.

${ }^{46} \mathrm{Cf}$. PIRSON (n. 4) 92. In his essay written about the peculiarities of the Latin inscriptions in Aquae Sextiae, J. Gascou interprets the form SVPESTES as the result of the reduction of the consonant group -rst- to -st-, see GASCOU (n. 16) 14. Pirson, however, identifies this change as assimilation. I tend to agree with Pirson, since there are examples for this change in other positions as well, for instance the Appendix Probi 149. cites persica non pessica, cf. PISANI (n. 36) 175. Furthermore, russum frequently appears in Plautus instead of rursum (e.g. Trin. 182).

${ }^{47}$ There are three readings of the inscription, which is lost. One of them contains only an indecipherable sequence of letters, while the others interpret the inscription as a dedication to Iuppiter Depulsor (Ioi Depussori), see GASCOU-JANON (n. 7) 161-162.

${ }_{48}$ LeUMANN, M.: Lateinische Laut- und Formenlehre. München 1977, 216-217. 
9. $-X$-. In the corpus, one can find many errors in writing the graph $X=[\mathrm{ks}]$. In the overwhelming majority of the instances (21 out of 29), $X S$ is written for $X$. This seems to be an orthograpic practice to maintain a 'correct' [ks] articulation. This orthographic solution goes back to the Sc. de Bacchanalibus, where the form exstrad appears twice, in which the sequence $-X S$ - is not etymological. However, one form shows the inversion of this orthographic practice: the etymological $-X S$ - is written with $-X$ in EXVPERIVS (Exsuperius, ILN 4, 13, 2-3; dat. 140-150). Apart from -XS-, the following graphic sequences are used for $-X$ - once or twice: $-C X$-, $-G X$ - and $-C S$-.

In Vulgar Latin, the consonant cluster [ks] was subject to assimilation to -ss(cf. It. vissi < Lat. vixi). However, the orthographic realization of this change seems to be sporadic in the epigraphic material examined. Only two instances show this change in writing: SANTIPPE (Xanthippe, ILN 2, A 75, 3) and $\operatorname{ISSI}^{49}$ (vixi, ILN 4, 149, 11; dat. 201-300) and one hypercorrect form betrays this process: MILIX ${ }^{50}$ (miles, ILN 4, 26, 4; dat. 101-160).

10. Word-final consonants. For the loss of word-final $-m$ there is only one firm example: SEPTE DIES (septem dies, ILN 4, 149, 14; dat. 3rd c.). There are, however, other forms lacking word-final $-m$ as well, yet in one case the form is at the end of the line. Concerning the rest of the instances another interpretation might be valid (for instance confusion between the ablative and accusative cases).

In the corpus there are 12 forms lacking word-final $-s$. However, approximately half of them are engraved at the end of the line, thus the elimination of the $-s$ can be interpreted as a form of abbreviation in these cases. In the other instances, again, the lack of word-final $-s$ might be attributed to some morphological error.

Finally, there is not a single example for the omission of word-final -t.

11. Greek consonants. Greek aspirated consonants were expressed with the corresponding unaspirated stops in the Republican times, then, starting from Cicero's age, they were transcribed with aspiration $(t h, c h, p h)$. In the corpus, there are some examples for the unaspirated transcription of Greek $X$ as well as of Greek $\Theta$. For the transcription of Greek $\Phi$, one can find both $F$ and $P{ }^{51}$ although the graph $F$ is slightly more frequent. Finally, there is one peculiarity to be noted: in the form GHOTYCVS (Gothicus, ILN 5.3, 914, 6; dat. 276) the aspiration of the consonant $g$ is an extreme hypercorrection.

After the detailed description of the Vulgar Latin phenomena collected from the corpus under examination, an attempt is to be made to characterize the general tendencies and developments in the Latin language of Narbonensis.

The vocalism of the inscriptions processed displays relative mobility: the most widespread Vulgar Latin developments are generally well attested. The two most characteristic phenomena in Narbonensis are the monophthongization of ae to open $e$ and the confusion between $E$ and $I$. In his essay written on the Latin language in Ro-

\footnotetext{
${ }^{49}$ The omission of the word-initial $v$-is probably a mere scribal error.

${ }^{50}$ Cf. Plaut. Cist. 728. mers (for merx) and App. Probi 30. miles non milex, PISANI (n. 36) 170.

${ }^{51}$ In Greek, $\Phi$ was first pronounced as [ph], then it changed to [f]. In the App. Probi, the transcription with $F$ counts as normative: 192. strofa non stropa; PISANI (n. 36) 177.
} 
man Gaul, József Herman points out that in Gaul the confusion between $E$ and $I$ appears in unstressed and stressed syllables in roughly equal proportions, whereas in the other provinces the stressed syllable tends to remain stable. This would suggest that the quantitative distinction ceased to exist in Gaul sooner. ${ }^{52}$ Our data, however, indicate that the Latin in Narbonensis is slightly different from this viewpoint: roughly in two thirds of the data the merging of $\bar{e}$ and $i$ affects the unstressed syllable. Thus, the quantitative distinction seems to be more persistent in Narbonensis than the tendency in the whole of Gaul would suggest. This can be further corroborated by the fact that in the overwhelming majority of the instances the monophthongization of ae to open $e$ indicated orthographically occur in an unstressed syllable.

The fact that only one firm example can be found for the merging of long $\bar{o}$ and short $u$ into closed $o$ is in concordance with the general tendency in the whole of Gaul: the merging first appeared among the palatal vowels and it reached the velar vowels only later in Gaul. ${ }^{53}$

In contrast to the vocalism, the consonantism of the inscriptions examined shows relative stability. The majority of the most widespread Vulgar Latin developments occur only sporadically in the corpus. Firstly, very few examples attest palatalization. Furthermore, there is not a single example for the confusion between $b$ and $v{ }^{54}$ Narbonensis proves to be extremely conservative regarding the elimination of word-final consonants as well: there is only one firm example for the loss of wordfinal $-m .^{55}$ Only one phenomenon in the consonant system is inconsistent with the tendency to relative stability perceived in the whole of Gaul: intervocalic $v$ proves to be unstable in several different positions.

Zsuzsanna Ötvös

ELTE Eötvös József Collegium

H-1118 Budapest

Ménesi út 11-13.

erinacea@gmail.com

${ }^{52}$ Herman, J.: La langue latine dans la Gaule romaine. In ANRW II 29.2. Berlin - New York 1983,1055

${ }^{53}$ HERMAN: La langue latine (n. 52) 1050.

${ }^{54}$ These results contradict HERMAN: La situation linguistique (n. 11) 458-460, where he claims that palatalization and $B \sim V$ alternation are more markedly present in Narbonensis than in the Tres Galliae. The territorial distribution of these two phenomena (and of two morphological changes) observed by Herman constitutes the basis of the distinction between the Latin used in Narbonensis and that of the Tres Galliae. However, this question can only be reconsidered after all the data found in Narbonensis have been processed.

${ }^{55}$ This is in concordance with the general tendency in the whole of Gaul, cf. HERMAN: La langue latine (n. 52) 1050. 